\title{
LibertyPress LibertyClassics
}

\section{Freedom} Federalism Felix Morley

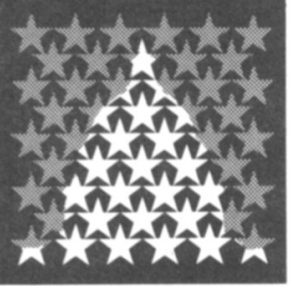

Freedom and Federalism

By Felix Morley

With a new Introduction by the Author

An historical analysis of the basic principles of government, with special emphasis on the transition from republican federalism to democratic nationalism in the United States. Dr. Morley sees the preservation of the federal principle as vital to the dispersion of political power and as required to protect individual liberty and to preserve social order in "a condition of freedom." He concludes that "the uncritical praise and practice of political democracy can readily be the highway to dictatorship in the United States." Hardcover \$8.00, Paperback \$3.50.

Prepayment is required on all orders not for resale. We pay postage on prepaid orders. Please allow 4 to 6 weeks for delivery. All orders from outside the United States must be prepaid in U.S. dollars. To order, or for a copy of our catalogue, write: LibertyPress/LibertyClassics

7440 North Shadeland, Dept. 222 Indianapolis, IN 46250 


\section{The Presidency in the Constitutional Order}

Edited by Joseph $M$. Bessette and Jeffery Tulis

These timely and perceptive essays present the views of political scientists rather than law professors to respond cogently to recently renewed interest in the American presidency.

$\$ 30.00$, cloth; $\$ 8.95$, paper

\section{Edward Douglas White}

Defender of the Conservative Faith

Robert B. Highsaw

Significantly, Highsaw demonstrates the influence on American public law by the "large and bearish man from Louisiana," who served on the U.S. Supreme Court for twenty-seven years. $\$ 20.00$

\section{Politics Is My Parish}

\section{An Autobiography}

Brooks Hays Foreword by Arthur Schlesinger, Jr.

"Some marvelous stuff-Brooks Hays memoirs are an important historical document and something of a tract for our times, or any other times for that matter." - George B. Tindall $\$ 20.00$

\section{Hitler's Secret War in}

South America, 1939-1945

German Military Espionage and Allied

Counterespionage in Brazil

Stanley E. Hilton

"Reads like a spy thriller."-Frank D. McCann

Hilton describes in detail the Allies' battle against the cunning Abwehr (German Military Intelligence), a struggle highlighted by the interception and deciphering of German radio transmissions. $\$ 20.00$

\section{The President and the Public Philosophy}

Kenneth $\mathbf{W}$. Thompson

This noted spokesman for ethics and morality in politics examines the problems of our nation and offers solutions and challenges to any citizen, especially one who trusts statistics like "a robot bobbing on an ocean of numbers." $\$ 15.95$

\section{Louisiana State University Press} Baton Rouge 70803 


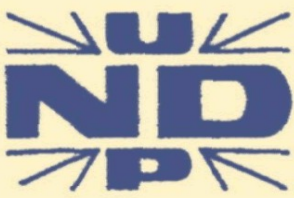

University of Notre Dame Press 